\title{
Be Content and Cherish the Present
}

\author{
Zhuojun Zhang and Xiangmeng Huang
}

\section{Interview with Ms. C's Parents}

C, female, born in 1992. The only child in the family. Grade III intellectual disability. Graduated from a special education school. Started working at Shanghai Papa John's in 2014

Interviewees: C's mother and father

Interviewers and writers: Zhuojun Zhang and Xiangmeng Huang

Interview dates: July 12 and August 24, 2016

Interview place: C's home

\section{A Lovely Newborn}

Q: Are you two from Shanghai? How did you get to know each other?

Parents: Yes, yes, we both are. We were introduced to each other by someone.

C's mother: We dated for more than a year. We were both above the average marriage age. I'm one of the "educated urban youth." I I went to rural areas, and later returned to Shanghai by taking over my father's job. We married in 1986, when I was already 35 , and he was 43 .

\footnotetext{
${ }^{1}$ Educated urban youth: To relieve urban unemployment and improve the backwardness of agricultural production, from the 1950s through the 1970s, young people were voluntarily or involuntarily relocated from cities and towns to the countryside or agricultural reclamation corps for farming jobs. They were referred to as "educated urban youth," and the majority of them were relocated during the Cultural Revolution (1966-1976). Most of them had barely finished middle school or high school, and only a small number held a Bachelor's or higher degree.
}

Z. Zhang $(\bowtie) \cdot X$. Huang

Fudan University, 220 Handan Ro., Shanghai 200433, China

(C) The Author(s) 2020

W. P. Alford et al. (eds.), An Oral History of the Special Olympics

in China Volume 3, Economy and Social Inclusion,

https://doi.org/10.1007/978-981-15-5005-8_10 
Q: What was your dream for your life when you just got married? For example, how did you plan your life? Where did you want to buy your apartment?

C's mother: We didn't really have a plan. That was before the implementation of the "Reform and Opening-up Policy," so people didn't have the concept of "buying an apartment." At that time, people like us were already pretty happy just to have a job. As "educated urban youth," we entered state-owned enterprises when we were back in Shanghai, and were quite content about our "iron rice bowl."

Q: How many siblings do you each have?

C's mother: I have two elder brothers and one younger brother.

C's father: And I have four younger sisters and three younger brothers.

Parents: We both have quite good relations with our siblings.

C's mother: We kept in frequent contact before getting married. Once married, everyone is busy. When you have kids, there would be more things to handle, then you would focus more on your own family. Mostly we just gather together during holidays or festivals now.

Q: When was your child born?

Parents: In 1992.

Q: There was quite some time between getting married and having the child.

C's mother: Yes, we had her more than 5 years after we got married.

Q: Was it because you didn't want to have a kid, or...?

Parents: No particular reason. It just happened that way.

Q: How did you feel when she was just born? What expectations did you have for her?

Parents: Of course, we were very happy.

C's father: (Laughing) You have your next generation! Every parent will have expectations for their child. At that time, we hoped that she would grow up well, be healthy, study well in the future, go to university, and later make contributions to the country... It's the same hope as any parent.

Q: Is her problem congenital or acquired?

C's father: Probably acquired.

C's mother: We don't know very well. During my pregnancy, I was told every time I had a check-up that things were fine, no problems. And we didn't have any family history of it.

C's father: My wife had reached a relatively advanced maternal age when she got pregnant. Her blood pressure was probably a bit high, gestational hypertension, or something like that...

C's mother: When did I have hypertension? My blood pressure wasn't high, but I did suffer from heatstroke right before giving birth. At that time the hospital facilities were not as advanced as now. There was no air-con and it was extremely hot. During the last days when I was in hospital waiting for the delivery, it was so hot that I couldn't sleep all day and all night. I just kept on flapping a fan. After getting the heatstroke, I had a fever. That was dangerous. The doctor put me on IV therapy immediately, then the fever went down. 
C's father: I rushed to the hospital when she got the heatstroke. The doctor explained the situation and asked me if I preferred to keep the mom or the kid if I had to choose. And I said that I want to keep both of them.

C's mother: For sure you should keep the mom.

C's father: I said that I want to keep both. Was I right? Why? She was not that young anymore, and neither was I. It was not easy to have a kid. That was why I said that I wanted to keep both of them. The doctor said, "We will just try our best." I waited at the hospital for 2 days. Later she got a bit better. During the delivery, I was outside the delivery room. I went to check with the doctor every 1 or $2 \mathrm{~h}$, "How are the mom and the kid now?" When she was born, the doctor told me, "Mom is fine, but your kid's fetal heartbeat was a bit fast."

But nothing else was found at that time. When the baby was born, they also said that she was fine. You see, in this case, we are both ordinary people, and medicine isn't our forte. Actually, even if you did study medicine, you might not necessarily know everything about gynecology or obstetrics. The OB doctors probably felt that the problem was solved once the child was born. When Mom got better and the baby's heartbeat was also better, they were discharged from the hospital. Nobody explained what caused the fast fetal heartbeat.

Q: How long was Mom's maternity leave after delivery?

C's father: She took the leave according to the government's regulation.

C's mother: I went back to work immediately after my maternity leave. That was 105 days after the childbirth.

Q: Then who took care of the baby?

C's mother: My mom and dad took care of her. When my daughter was about three, my dad, her grandpa, passed away due to a sudden asthma attack. My mom had already had a stroke before that and was not so fit, so nobody could care for my daughter anymore. Then we sent her to daycare. But she was not used to it and was ill with a high fever. Then we had to send her to my mother-in-law. Our factories had started to give 2 days' leave per week, so every week I took care of the child for 2 days, Dad for 2 days, and the other 3 days were covered by my mother-in-law.

$\mathrm{Q}:$ When did she learn to talk?

C's mother: She began to say simple words around the same time as her peers.

C's father: She was about 1 year old when she started to say "daddy" and "mommy."

C's mother: Walking was also pretty early. She started to walk when she was 14 months old. Nothing strange could be found at that time.

Q: Mom and Dad, do you still remember some lovely details when she was little?

C's father: She was extremely cute. When she was around 2 or 3 years old, we walked on the street holding her in our arms. She would smile to others. People would always give compliments about how lovely she was.

C's mother: She didn't just smile for nothing. She smiled to people if she saw a nice-looking person. She could distinguish if others were pretty or not. Once she had a high fever. We took her to the hospital on Huanghe Road, which was famous for its pediatrics. The doctor said to us, "Wow, what a pretty kid! A gift from heaven! Lucky you!" She was very pretty when she was little. No exaggeration-her skin 
was white and bright, and her eyes were big. Now she has put on some weight, and the eyes have become smaller. But now she also wants to be pretty. For dinner she will only eat some vegetables in order to lose weight.

Q: What did she play with when she was little?

C's mother: We bought building blocks for her, as well as building pieces and intelligence toys. We live close by the Bund, so we would walk around there on our days off. She liked singing. At that time the TV series Sinful Debt was broadcasting. ${ }^{2}$ If I started singing, she would follow and sing along its theme song. She could also sing the song Mom Is the Best in the World. "Mom is the best in the world. A child with Mom is like treasure." These she could all sing when she was little. I might even have kept the cassette recording of her singing. Now she still likes listening to music. Sometimes she'll use music apps on her mobile. She likes the current popular songs. People of our generation don't really like them. We prefer sentimental songs. When she was little, I also taught her to read children's rhymes. She could follow me to read. And she could recite poems when she was little. I don't know why, but she had a very good memory.

C's father: Later when she was in third grade at elementary school, there was a time when the teacher asked them to recite poems from the Tang Dynasty during self-study time in the morning. She could do it. If you asked her now to recite some Tang poems which she had learned before, with a little help, she could still do it.

Q: You two really paid a lot of attention on her early education.

C's mother: Yes. I even took early retirement for her. I could actually have worked several more years. So now my pension is also a bit lower than others. But I didn't have any other choice.

\section{Showing Signs of Intellectual Disability}

\section{Q: How old was she when Mom retired?}

C's mother: She was at the age to go to nursery school when I retired. We noticed at that time that she was rather introverted. She was quite interested in participating in dancing or doing morning exercises, and she could follow the rhythm. I always stayed outside to watch her after bringing her there. She did it pretty well. But she didn't talk much.

C's father: She was quite introverted and didn't talk a lot. When she was about 2 years old, she had a fever. We took her to the pediatrics department and said to the doctor, "Our daughter hasn't started to speak." The doctor said, "That doesn't matter. Children start to talk at different times. And the ones who speak later are usually smarter." Even the pediatric doctor said this, so then we didn't pay much attention anymore.

\footnotetext{
${ }^{2}$ Sinful Debt: A popular TV drama in the $1990 \mathrm{~s}$ about the life of the "educated urban youth" and their abandoned kids.

${ }^{3}$ Mom Is the Best in the World: a popular children's song.
} 
When she was bigger, she went to nursery school. At first little was noticed. The teacher only commented that she was a well-behaved girl who was not talkative. But later the teacher told us that she was quite introverted and didn't mingle with the group. She always stayed alone. One day the teacher missed her in the class, so the teacher went to look for her. She searched and searched, and found her playing alone with water. She put on soap then rinsed it off with water, and then put on soap again and rinsed it off again... Even when she did sit together with other kids, she would still look around. Later the school principal suspected that she might have autism and suggested that we take her to hospital for a check-up. We took her to see a specialist at the Children's Hospital on Beijing Road. The doctor said nothing but that we should "strengthen education."

C's mother: Strengthen education and communicate more with her. She was pretty quick at completing puzzles during the exam. So they said that she had pretty good logical thinking. But we didn't receive any diagnosis.

If she really had autism, she wouldn't be able to learn different things. But she did quite well in morning exercise and dancing. We had quite good relations with Ms. Sun, the teacher at nursery school. She would tell us what had been taught in class every day. Then we would review it with her every evening. It took us quite some energy. This way she could keep up, and sometimes she could even do a bit better than other kids. But we underestimated the problem at that time.

Then she went to elementary school. Even in first grade, problems already emerged. She couldn't keep up anymore. She was slow. We parents went through a tough time. She was so slow that we finished almost every night around 10 p.m.

The students were supposed to write down the homework list. She was too slow so other kids would write it down for her. We would then monitor her to finish it according to that list. At first, she needed to copy pinyin and new Chinese characters. For math, at first she just needed to copy the numbers. She was just slow. To write from memory, she might be able to do it if it was taught the same day. But if it was taught several days before, then she couldn't. She had very poor memory, and that made the study difficult. So we kept on repeating to enhance her memory. On one hand she had to finish the homework of the day. Then we would still guide her to read the new characters, and then make her write from memory. On the other hand, we also needed to enhance the things she had learned previously. It took her much more time than others. It was quite strict at elementary school at that time. You had to finish your homework of the day and the next day you would have dictation. The problem was obvious. She just couldn't keep up.

Q: Wasn't she doing quite well in math when she was at nursery school?

C's mother: No, not really. At nursery school she could recognize the numbers quite well. As soon as she went to elementary school, it became difficult for her.

C's father: When she had to do addition and subtraction and so on, she was not sensitive to numbers. And she had a really short memory.

C's mother: Poor memory. Actually, smart kids all have a good memory. They are savvy.

Q: How about her concentration?

C's mother: She has less concentration than some kids. 
C's father: She would concentrate if she could understand or was interested in the topic. Otherwise she couldn't stay focused.

C's mother: That was a painful period for us. Our kid didn't do well in study. But the teacher would announce everyone's scores. When her score was announced, some smart boys would... I used to bring her back to school after lunch and I would hear others calling her "blockhead." My tears... my heart was aching. Though she did have problems, she shouldn't be treated like that. She is also a human being, isn't she? Other kids at school were also just first graders and they didn't know better, so I couldn't really blame them. Our experience of raising her was... Now we are really satisfied with her current situation and her job. But in fact we've really gone through all kinds of hardships. What a path we've followed, full of twists and turns!

C's father: It was also tough for her.

C's mother: She also had a hard time. We kept on pushing her, with no result. That was really painful. Some teachers could understand and they would be reasonable with us. But some teachers couldn't understand and they even... It was indeed unbearable...

Q: Could most teachers somehow understand, or not?

C's mother: Most of them couldn't understand. Especially when she just started in first grade. The teacher would even give negative comments. At that time, the upgrading ratio of each class was linked to the students' scores of exams. Your bad score would affect the performance of the whole class, as well as the teacher's performance.

Q: Did the teacher criticize her in front of the whole class?

C's mother: It might have happened sometimes.

C's father: We don't really know.

Q: Has your daughter mentioned it when she came back?

C's mother: She just said, "Mom, I don't want to go to school. I don't want to."

Q: That indicated that she was not happy at school.

C's mother: Yes. She would lose her temper as soon as she got home. She was very moody. Nobody talked to her the whole day. It was tough for her.

C's father: At home, sometimes she would lose her temper for no reason. That was a way to vent her emotions.

C's mother: Yes, she was venting her emotions. A general school gave her too much pressure. It was not that she didn't want to perform. But she has her limits. She couldn't help it.

Q: What was it like when she lost her temper?

C's mother: She wouldn't tell us what happened, she would just have a tantrum. When she was at nursery school, she would cry and lose her temper at home in the evening. After entering elementary school, her self-esteem also developed. So whenever she was treated badly at school, she would come home and say, "I don't want to go to school! I don't want to go to school!" We couldn't bear it anymore. It seemed that she could no longer continue at that school. The school suggested that we have her IQ tested somewhere. We couldn't reach an agreement in a pleasant way.

Q: How did you feel when you heard this? 
C's father: At that time, we didn't have the idea that "my kid might suffer from ID."

C's mother: It was not talked about much, not like nowadays.

Q: People were not educated about the concept of ID.

C's father: No, it was not known. And actually even the doctors at the Children's Hospital have also only just been exposed to that.

C's mother: Yes, it has just started. We didn't know much about it in the beginning either. We were worried but we knew nothing about how to guide the kid and how to educate her. So we were just worried but couldn't find any solution.

\section{The Tough Treatment}

Q: When was it diagnosed?

C's mother: That was at the time when she couldn't keep up in first grade and the school suggested an IQ test. Basically, they didn't want to have her anymore. The test result was a bit lower than the normal score of 60 . But the doctor said that she was pretty good at logical thinking and that she completed puzzles quite well. She is very timid and introverted and is afraid of strangers. Therefore, the IQ test might not reflect her true situation.

Q: So, at that time, did you want to transfer her to another school, or did you want to have her treated?

C's mother: We sent her to see the psychiatrist at the Central Hospital of Xuhui District. It cost us a lot of money.

Q: Did you make her see the psychiatrist because you thought she had autism?

C's mother: We would take any suggestions which might help her. We took her to see the psychiatrist, and took her to do physical exercise. That was also in a hospital in Xuhui District. It cost dozens of yuan each time. It was said that this kind of physical exercise could help improve her intelligence. For example, she would walk on the balance beam, glide down from a very high place, and jump on a trampoline, and things like that. We took her there once or twice a week. And we also took her to another place for activities like storytelling and number guessing in order to develop her intelligence. So we took her to various activities and bought whatever medicine that was supposed to help her. During summer and winter vacations, we would make her take shots that could nourish the brain. But all these seemed to deliver no concrete results. We spent a lot of money on all these, in the hope that she would eventually get better. But the reality was a bit far from our expectations.

C's father: It was a lot of effort.

C's mother: True, effort and money. It was really tough, really.

Q: Did you both accompany her every time?

C's mother: Yes, we both went together with her.

Q: Some parents might think of abandoning their kids once they find out that the kid has ID. Have you ever had similar thoughts? 
C's mother: No, we haven't. We want to take extra good care of her because of her condition. Why do we say this? They say that you are chosen to have this kind of kids because you have a loving heart. Traditionally people believe in this. The more defective she is, the more we should love her, shouldn't we? Recently I wasn't feeling well and had a fever. At night I wanted to drink, and she would get up and get water for me. I was quite touched.

Q: When you first found out about her intelligence problem, what was your initial reaction? Did you want to hide the fact from others, or did you want to ask for help from relatives and friends?

C's mother: We didn't try to hide it. My mother-in-law is a frank and straightforward person, so all relatives in our family know about it. Actually, I would have preferred to keep it a secret. I didn't really want others to know my kid's condition.

Q: What was your thinking?

C's mother: I just wanted to protect her. Even now I still don't really want to talk about it. I also had hesitation about this interview. I feel like I should protect her and don't want to let others know about her condition. I gave birth to her to be like this. Really, I feel very guilty (holding back tears). I also wish that she could just be like you. At that time I could hardly accept this fact. I thought what bad luck I had. I'm always willing to help others and I'm kind. What did I do to deserve this? Even now I still don't really want to talk about it with others... Then Dad went to the orientation. And you said that we could use aliases and the photos would only show her profile and her back. Then I decided to cooperate and accept this interview. I believe that each family with such a kid (holding back tears again) would share my concerns. That is pretty normal. There's nothing I can do now. So I can only hope that she can be happy and that I can protect her well. I wouldn't ask for anything more than that, nothing else at all.

C's father: In fact, as parents, we just hope that these kids can be understood in society and that people can show respect to them. We hope that we can protect them. But this won't be realized if we are alone. We need help from society. Everybody should understand that.

C's mother: We really hope that everyone in society can understand us.

\section{The Lonely Journey of LRC}

C's mother: Our daughter didn't even finish first grade. She quit in May, during the second term. We couldn't stand it. We figured out that the environment was really not favorable for her. We wanted to switch her to a school with a better environment and with teachers who would be kind to her. It might have been favorable to her development both physically and psychologically. So we asked for help from our matchmaker, a teacher at Shanghai Normal University, to transfer my daughter to another school. In September, we registered at the new school and she started first grade all over again. The new school was in Xuhui District while we lived in Hongkou 
District. ${ }^{4}$ For her study, we had to rent a place to stay. Because she entered this school via an acquaintance, the environment around her was a bit better.

C's father: Later on, the Education Bureau issued the "LRC Policy,"5 meaning children with ID study in regular classes together with normal children. But the requirements for children with ID are different from the ones for the normal children. It was hoped that children with ID could develop healthily in a regular environment. If you still couldn't fit in such a situation, you could be transferred to a special school.

C's mother: So she was studying in a regular class like this. She made slow progress, while other kids made fast progress. Her exams were also a bit easier. She went to the after-school nursery class when she was studying at this school, so that she could do her homework together with other kids. But her tempo was slow, so she still had to do more when she was home.

C's father: She went to this regular school together with normal classmates, from first to fourth grade. She did have pressure from this LRC. Why was that? She had problems. Her classmates were all normal, and they didn't have much contact with my daughter. She was left aside on her own and was very lonely. When she was studying at the second school, I once went to pick her up after school. It was in winter and they were having an outdoor activity lesson. All kids were playing the "Chicken against Eagle" game, except for her-she was running on her own behind them. 6

C's mother: Partially maybe because these kids were still very young. An adult in this situation might help her. But the kids didn't understand. If people like you saw a similar situation, you would definitely want to help her mingle with the group. So we couldn't really blame those kids, could we?

Q: How was the environment at the second school compared to the first one?

C's father: It was a bit improved. She was not the only LRC student at school. There were more in other classes as well.

C's mother: It was for sure better than the first school. Nobody would insult her directly anymore.

Q: Did she continue all the way at the second school?

C's father: She continued until fourth grade, when she really couldn't keep up with the class anymore. The class teacher suggested that we'd better transfer her to a special school. The teacher simply said, "It doesn't make sense to keep her here any longer. It's also very painful for her. As teachers we can't do much. I'm sure you can understand the situation - there are so many students in the class that it's impossible for me to tutor her alone. I have to take the majority of the students into consideration. Remaining is really not to her benefit. If you insist, I could pretend

\footnotetext{
${ }^{4}$ These two districts are located at the west and east of Shanghai City respectively and are regarded as quite far when traveling by bus.

${ }^{5}$ Learning in regular classroom.

6"Chicken against Eagle": A traditional Chinese game for children. One child acts as the mother hen, standing in front of a queue of children acting as chicks, with his/her arms extended, in order to protect the chicks from being caught by the eagle, which is acted by another child.
} 
and let her go to fifth grade, but that wouldn't be responsible for you parents and for the child."

One day I happened to be at school when the bell rang at the end of a lesson. I stood at the classroom door, and saw that $C$ was napping with her head resting on the desk. Because she couldn't understand, she found it boring to listen. And every night she would do her homework until very late. So she was tired. The Chinese teacher just let her sleep and didn't bother to wake her up. If she was woken up, she couldn't understand what was being said anyway. So $\mathrm{C}$ also didn't have a choice.

\section{A Smooth Path at Special School}

C's father: Then we decided to let her go to a special school, where special education methods were adopted. She started there in 2006. For entrance, each kid would be assessed in hospitals at a designated time every year. When we went for the assessment, we missed one document. So we couldn't proceed with the assessment while all other kids completed it. The next year, we took her to No. 6 People's Hospital for an intelligence test. Her intellectual disability was then confirmed. And later we also applied for an ID certificate for her, right before her graduation from this school. If she didn't have the certificate, people would set higher requirements on her, just like normal people, and we needed it if she wanted to continue studying at JiXun School, or if she wanted to work.

Q: In which period did she have a better mood, at regular school or special school?

C's mother: At special school, for sure. Because everyone was in a similar situation. Nobody would laugh at others or look down upon others. The teachers there are more professional. They have studied Special Education, so they know how to treat these kids. The teachers teach at a slow tempo. Imparting knowledge is no longer the key issue. The main purpose is to develop the hands-on and self-care abilities of the kids.

Q: What are the subjects at special school?

C's father: The subjects included Chinese, math, music, and fine arts. They also had Social Practice Lessons, in which they were taken out of the school to visit supermarkets, shops, and the neighborhood to get in touch with society. There was one more lesson which you couldn't find at a regular school: cooking. They were taught how to cut food up and cook. At that time, she would also cook some dishes at home, such as fried eggs with tomatoes and Gong Bao chicken, ${ }^{7}$ and so on. Those were her assignments from school.

Q: The subjects were quite interesting.

C's father: Yes, they were. And most importantly, the kids experienced a sense of achievement after learning all those things.

C's mother: You probably wouldn't expect it, but actually these kids also have pretty strong self-esteem.

\footnotetext{
${ }^{7}$ Fried eggs with tomatoes and Gong Bao chicken: Typical dishes of Chinese cuisine.
} 
C's father: The intelligence levels of her peers at the special school differed. Since she had been studying at regular schools, it seemed that she performed even better than others at special school (laughing).

Q: Did they have any extra-curricular programs at school?

C's mother: In 2007, the International Special Olympic Games were held in Shanghai. $\mathrm{C}$ was in fifth or sixth grade. Her whole class went to rehearse, preparing for the Group Calisthenics at the Closing Ceremony. During the games, the school offered plenty of activities for the students outside the school.

C's father: Apart from the performance in the Special Olympics Games, they also went to Nanjing Road, to perform in public. They also performed at the Metro Plaza. ${ }^{8}$ I was there during both performances. They were singing Grateful Hearts. She acted quite naturally, and was not shy. She was quite pleased whenever there was an activity like this. Though she didn't say it, we could still notice it on her smiling face when she was home after her activities.

The school organized activities frequently at that time. After the end-of-term exams, the whole school went for an outing in a rented bus. They went to have Western food and watched a movie. They had a variety of activities. They went to the Safari Park, which even I have never been to. The special school has many sponsors. Some of them support in the form of money or donations, while others contribute with materials.

C's mother: In this sense she has experienced quite a lot. The teachers of this school always emphasized that they should connect more with society.

Q: Among all these subjects and activities, what was her favorite?

C's father: She has never told me which her favorite was. Has she mentioned it to you?

C's mother: No, she hasn't.

Q: She is a rather introverted person.

C's mother: In fact, her character is like mine. When I was young, I was also an introvert. Now that I've gotten older, I talk more.

Q: How was her grade determined at special school?

C's father: She was supposed to be in fifth grade when she started at special school, but the principal discussed with me about putting her in sixth grade. There are in total nine grades at special school. So, she has studied there for 4 years. After that, she passed the entrance exams for the vocational school.

Q: So there are also entrance exams for the vocational school?

C's parents: Yes, there are.

C's father: And that is JiXun School.

Q: What were the entrance exams like?

C's father: We first signed her up at school. Then all students gathered in one classroom. Parents stayed outside. The students filled in an application form, with their names, genders, and addresses and so on. That was pretty simple. After that, they went to different testing rooms. It seemed that she was asked to finish an assignment. The door closed so I couldn't see much. Mainly she was tested about her hands-on

${ }^{8}$ Both Nanjing Rd. and Metro Plaza are busy downtown shopping areas. 
abilities. There were no separate written exams. Filling in the forms were already the written exam. Some of them couldn't complete that task. One of her ex-classmates couldn't write a single word on the form, and she was not accepted.

Q: Now she works at the restaurant. Did she study cooking at school?

C's mother: No, she studied Supermarket Merchandising.

Q: Did someone choose that major for her or did she want to learn it?

C's mother: It was designated by school.

Q: Did she talk about what she has learned in detail?

C's father: Yes, she did. Sometimes she would ask me to accompany her in the evening while she was doing her homework. She got a lot of studying materials, such as Food Safety, how to place products onto the shelves, how to sort, for example how to place dry products, and how to check the date of perishable food, and put products with shorter expiry dates to the front and the ones with longer expiry to the back. Most of these things needed to be memorized by heart. A lot of details. In addition to this subject, she also had Chinese, singing, and PE. Also, for the assignments for these lessons I accompanied her to finish.

Q: How would they be tested during exams? Would there be a ranking of scores?

C's mother: There was no ranking. Those kids all had ID, so the emphasis was on their hands-on and self-care abilities. They were taught by the teachers to be "strong and independent." This was frequently emphasized. "I want to work" and "I can" were ideas taught to them. They did have mid-term and end-of-term exams on subjects like Chinese, math, ideological and moral education, and physiological health. They also had practice exams, in which they were asked to cook a dish. We also received performance reports after exams, and we attended parents' conferences as well, when the teachers would then communicate with you about your kid's performance.

C's father: She has been in the vocational school for 2 years. Actually, she has had lessons for about 1.5 years. During the last 6 months, there were various employers coming to their school for recruitment. And then they were waiting at home for notice. C didn't get a job in the first year. So, she stayed at home for an extra year, in total 1.5 years.

Q: How did she spend that year while she was waiting for a job?

C's mother: We taught her at home how to take care of herself in daily life. We took her to the open market to buy fresh food, to do housework like washing vegetables. We mainly focused on enhancing her ability in this area. The rest of the time, she would work on her handwriting, do some homework and review her previous learning materials from school. She did some math assignments and learned to write new characters.

Q: Does she do well in recognizing characters now?

C's mother: I feel like she is much better than before. Now she will key in the text by handwriting when she chats with her colleagues on WeChat.

C's father: She is not so good at keying in by pinyin. But she can write the characters well.

C's mother: She wouldn't let us see her WeChat. She said that it's her privacy.

C's father: She does get upset if we touch her mobile (laughing). 
C's mother: Let's show them C's photos on our mobiles. You couldn't see her problem from her appearance at all. She's quite capable. Why do we say so? When she was studying at vocational school, which was quite far from our current home, she commuted on Bus No. 50. Starting from the bus stop of No. 50 close by, she would travel all the way to the bus terminal at the crossing of South Zhongshan Road and Dong' an Road. One time the bus broke down and couldn't move anymore. When she was home, she told us that the bus she took was out of order. Dad asked her, "Then what did you do?" "I just waited for the next bus and then got in again, of course, together with all the other passengers." That happened when she was still at school. We were quite relieved when we heard that!

\section{Hardworking and Kind-Hearted}

Q: Did she apply at Papa John's because she wanted to be a cook?

C's mother: Not really. Not every student got a job after graduation from JiXun School. There were more than a dozen students in her class. Only four were chosen by recruiting parties. She didn't get a job, so she waited at home, without a job for more than a year.

Talking about Papa John's, they happened to be recruiting this group of kids in other districts. Enquiring at the company, we were told that there were job vacancies and that we could hurry to an examination venue on Wuning Road. We took her there and she was immediately called in for an interview. Afterwards, the examiner told her that she would be tested for making a crust and that she should practice at home the proper movement of her hands. The next day she was asked to make a pizza crust, and she completed the assignment.

C's father: When we were still on our way home, we got a phone call from the proctor asking when she could register at the company.

Q: Did you get this recruiting information from school?

Parents: No, we didn't. We went to enquire at Papa John's on our own.

C's mother: We have heard of Papa John's because they came to her school to recruit among graduating students a year prior to her graduation. But when $\mathrm{C}$ graduated, they didn't come for recruiting. We thought that this company must be a place with love since they accepted these special kids, so we took her to the company and enquired with the manager.

Q: She prepares snacks at the restaurant. What kind of snacks?

C's father: Like chicken wings and pasta and things like that (See Fig. 1).

Q: She's like a cook.

Parents: Yes, she is a cook.

Q: After she started working, was there anything especially impressive to you?

C's mother: When she started working, one day the bus didn't take the usual route. She noticed that was not the bus stop where she normally got off. The weather was hot and she was worried to death. She got off the bus and asked people, "Where is South Shanghai Station?" People showed her the way. At that time, the restaurant 


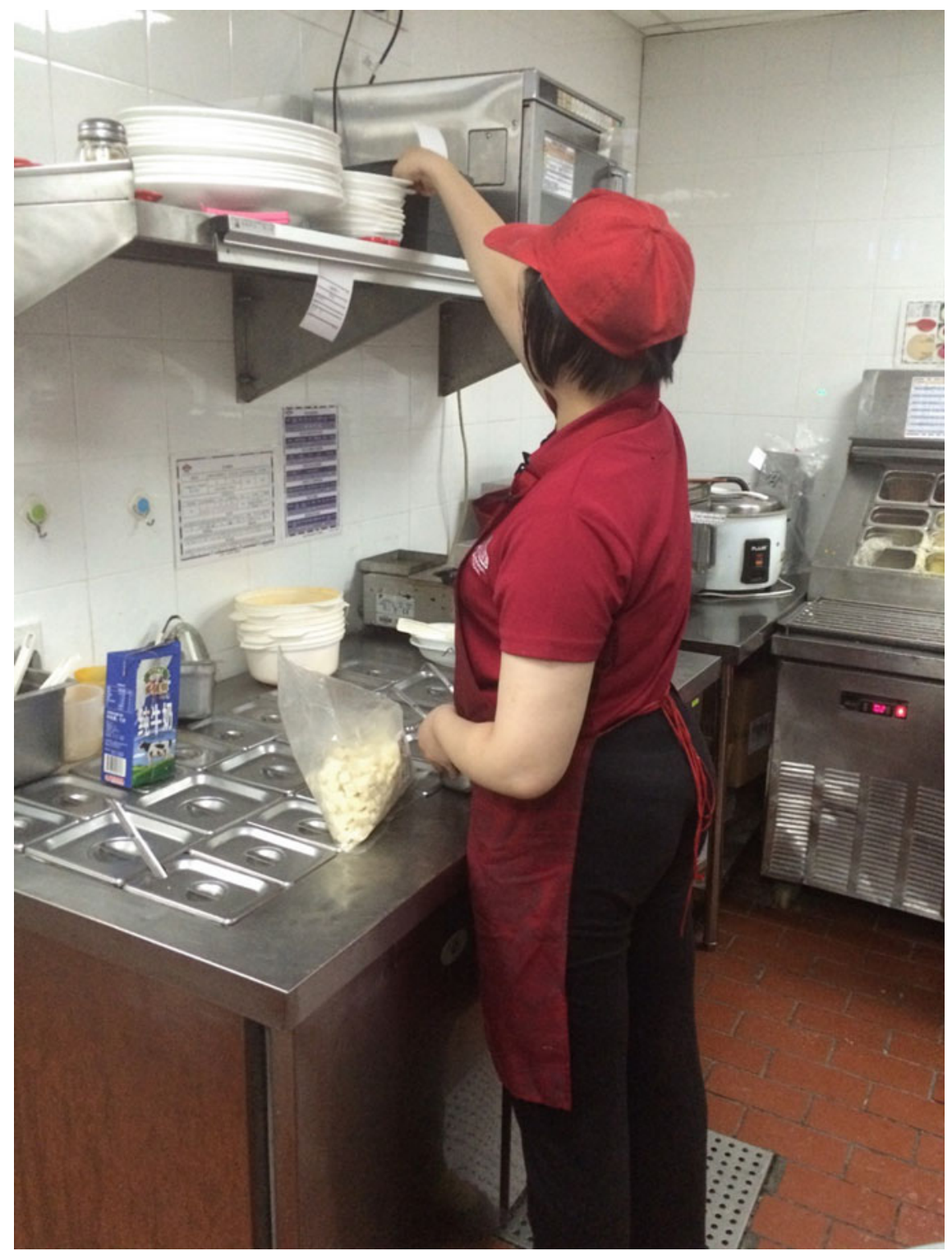

Fig. 1 Ms. C at work

called us and asked, "Will C come to work today?" We also got very worried. She set out very early. How come she still hasn't arrived? Just at that moment, I heard over the phone that she arrived. She was supposed to start at 11 a.m., and she arrived just 1 or 2 min before that time, covered in sweat. Later she told us that the bus didn't take the normal route. She noticed it when she got off and asked for directions. That 
happened not long after she started with this job. She knows the way better than I do. When she worked at Tian Lin Branch, she also once took the wrong bus. She should have taken Bus No. 131, but she didn't see clearly and took No. 731 instead. She noticed the mistake after one stop. She didn't want to be late for her work, so she took a taxi. I found her quite resourceful.

Parents: Some kids might not react so quickly. I will be late for work... What shall I do?

Q: And she is very responsible. She hurried to the restaurant in order not to be late.

C's mother: And now she is still like that. Her work starts at 10 a.m. now. She would set off around 8:40 or 8:50, so she arrives a little later than 9 a.m. Ever since she was little, she would not skip school, even when she was not well.

C's father: Our daughter has never been late, neither for school nor for her work. She also wouldn't play truant. She likes to go to school, and to her work. And she prefers to be there early. She doesn't want to be late.

C's mother: She arrives early. Her work starts at 10 o'clock, but she arrives immediately after 9 a.m.

C's father: She is quite disciplined.

C's mother: I feel that she has become much more open, ever since she had this job and started to get in touch with society. The restaurant where she works now is just like a big and loving family. The manager gets along with all the colleagues. She's happy and talks much more than when she was studying. Whatever happens at work, she will tell us when she's back. She has become more cheerful. Although she only gets the minimum wage, her life is secure, right? Actually, we as parents are also pretty satisfied. Quite a lot of her schoolmates at the vocational school don't have a job and stay at home. We don't ask much and we don't compare our daughter with others who are in a better situation. You'd better be content with the things you possess. There are still kids staying at home. They couldn't get into society and don't have a job. Those people must envy us. Whether your kid could have a job will have an impact on how the parents feel. Kids like them should be given the opportunity to get in contact with society. This way they can realize their values-I want to work and I can do it.

I encourage her frequently. It's important for her to hear me saying "Yes, you can." Several days ago, I made a digital album with an app named Xiaoniangao. The next morning before she went to work, I demonstrated it to her one more time and asked, "I'm making it now. Do you get it?" "No, not really, Mom." Later, during her lunch break, she managed to make the digital album and sent it to us. I suspect that she might have some talent on the computer. She's very quick in learning things related to computers, whereas we parents cannot even do it.

C's father: She plays with the mobile better than we do.

C's mother: She usually talks about things happening at the restaurant, like who is ill or who is on annual leave. "But they wouldn't travel during their annual leave," she told us, "their parents wouldn't take them out traveling."

All: (Laughing). 
C's mother: Several days ago she told us, "Manager Sun said that you two could take me traveling during my annual leave." "We are planning on that. July is too hot. Let's go somewhere in October,' I said.

C's father: They have 9 days' annual leave to be taken in two parts. She can take a few days off in the hottest season for some rest, and then spend the rest traveling when it gets cooler.

Q: Did she talk about what happened at school when she was studying?

C's parents: Not so much at the time. But now, on one hand she is older and her intelligence has developed further. On the other hand, after she got in touch with society, she sees more things and has more to share with us. When she was little, she would be busy having lessons the whole day and finishing her homework. There was not much time to talk about other subjects. She had so much homework that she could hardly finish it.

Q: How does she get along with her colleagues?

C's father: She said that her colleagues are all kind to her. Sometimes she will bring snacks to share with her colleagues, and they will do the same for her.

Q: Do you still remember how she spent her very first salary?

C's mother: Normally she receives her salary in her bank account. When she got her first paycheck, her grandma, my mother-in-law, was hospitalized. She bought Grandma something from Harbin Food Factory on Huaihai Road with her salary. Grandma was very pleased. ${ }^{9}$

C's father: (Laughing).

C's mother: Her school has always put emphasis on this. During her last school year, the teacher told them, "You must work hard. What should you do with your first salary? You could buy some nice food for your parents and the elders in your family." That's how she was taught.

C's father: She is a kind person, with a gentle heart.

C's mother: We have good relationships with our neighbors. If they travel somewhere, they would bring back something to us. My daughter said to me that we should also bring back things for our neighbors if we go traveling. I told her that I will remember to do so. She's good at keeping a good relationship with others.

C's father: I remember one more thing. When she was at JiXun School, she was studying Supermarket Merchandising. They got a sheet with a table to record down product names. One sheet for each student. You use pencil to write, so it can be erased and re-used. Some kids erased too hard and the sheet would rip. Sometimes she would also make mistakes on the sheet. So I made extra copies of the sheet and put them in her bag. She sometimes would give the copied sheets to her classmates if they damaged theirs.

C's mother: She is pretty generous.

C's father: She's big-hearted.

Q: Okay, she's like that. And does she take care of her salary by herself now?

\footnotetext{
${ }^{9}$ Harbin Food Factory: A local food factory with a long history, located in the central commercial shopping area. It specializes in traditional Chinese snacks as well as Western-style baked snacks, and frequently has customers queuing to purchase the popular items.
} 
C's mother: We give her a certain amount of allowance. And we will buy the things she likes to eat. We basically don't touch her salary. Now she has a job, but what if she becomes jobless in the future? Nowadays you can only receive pension after retirement if you contribute a minimum of 15 years to the pension fund, right? ${ }^{10}$ So we don't use a cent of her salary. We just save it for her. In case she becomes jobless, she can still continue paying to the pension funds with that saving.

Q: What does she normally like to buy with her allowance?

C's father: She won't waste money.

C's mother: She sometimes will buy a lemonade when she's thirsty. And sometimes she'll bring back food to let us taste. She will also buy things other than food. She has a kitty umbrella. (The parents took out a pink Hello Kitty umbrella.) It cost dozens of yuan and she bought it by herself.

Q: So she loves cute pink things like this.

Parents: (Laughing).

C's mother: When it gets cold and her lips are dry, she will also buy herself a lip balm.

C's father: Once it was hot, she went to Daphne and bought a pair of sandals. ${ }^{11}$

C's mother: That was during the first year when we started to give her allowance. The sandals were 168 yuan and she bought them by herself. She took them back one day after work. Now if she's hungry, she might go to McDonald's for some food. We give her several hundred yuan each month. She spends it carefully. She won't spend like crazy, so that's very good.

\section{Simple Relationship and Family Trips}

Q: Did she have contact with her classmates and friends when she was little? Did they come to play at your place?

C's mother: When she was in first grade, the neighborhood kids would come here to play. She wouldn't go out. Others came here.

Q: Did it happen when she was in the first elementary school?

C's mother: Yes. And it didn't happen anymore when she switched schools.

C's father: After she started at JiXun School, she had more in common with her classmates there. They shared the same interests, and they would come here by themselves. Our daughter would tell us that someone wanted to come to play. We told her that it was fine, and she would then ask her classmates to come. Her classmates took the initiative to play here. C didn't invite them by herself. But of course, she liked it if her classmates were willing to come.

\footnotetext{
${ }^{10}$ Pension Insurance: Normally one has to contribute a minimum of 15 years to the pension fund to be entitled to a monthly pension after retirement.

${ }^{11}$ Daphne: A popular Chinese brand for women's shoes with many exclusive stores and counters.
} 
C's mother: Now there's also a colleague at the restaurant who sometimes comes here. We are more than happy to have guests, as long as they are happy. I hope that she can become more cheerful with the friendship.

Q: Does the colleague friend who came to your place also have ID?

C's mother: Yes, she does. Some of those colleagues are older than she is.

C's father: Her social circle is not as wide as you normal people. They would just chat on WeChat or via telephone among classmates.

Q: How does she get along with colleagues without disability?

C's mother: The normal colleagues have never come here. Most of them are married and have become parents.

Q: Is there any change in her response to strangers nowadays compared to previously when she was little?

C's mother: She won't talk to strangers. We have specially warned her not to, especially strange men. I told her, "When Mom was at your age, I wouldn't talk to boys. What if the stranger is a bad guy and wants to take advantage of you? Girls have to keep their self-esteem and protect themselves. You must keep these two points in mind. Don't respond or talk to strange men." I keep on repeating it frequently, so she knows it. Recently she told me, "Mom, there was a man on the bus who kept on looking at his belly button. And the woman next to him kept on staring at him." I said to her, "This man either has some mental problems, or might be a bad guy and tried to seduce girls like you to watch him. What if he acts indecently?" "I didn't look at him and I don't want to. The woman next to me was watching, not me," she said. Things like this we have to warn her frequently, as an alarm. Actually, she must also have looked. Otherwise how could she know that the other woman was watching? I just didn't want to point it out. (Laughing).

C's father: When she was at special school, they also had a subject probably called "Society and Morality." Its study book also mentioned "no talking to strangers." They were taught so at school. They were taught to keep away if there's anything happening on the streets. That is because kids like them are naïve and might not be able to distinguish in most cases. So they have to learn what they can do and what they shouldn't do.

Q: When C was at school, did you take her out on weekends?

Parents: Yes, we did.

C's mother: When she was little, we took her to places like Shanghai Zoo, Safari Park and Aquarium. The admissions are not cheap. But we've taken her there.

C's father: We've also been to the Oriental Pearl. ${ }^{12}$

C's mother: We've taken her to Oriental Land Holiday Village as well. Sometimes we also went out of Shanghai. When she was at nursery school, we took her to Hangzhou. And we've also been to neighboring Tong Li Old Town and Suzhou.

Q: Did you also visit the Expo ${ }^{13}$

\footnotetext{
${ }^{12}$ The Oriental Pearl Radio and TV Tower is one of the architectural landmarks in Shanghai. At $468 \mathrm{~m}$ in height, it used to the tallest building in Shanghai in the $1990 \mathrm{~s}$, and is currently the third tallest.

${ }^{13}$ This refers to Expo 2010 Shanghai.
} 
C's mother: Yes, we did. We went there three times. She was pretty big at the time of the Expo, so she can remember. We as parents would just do our best.

Q: Do you have family outings now when you have time?

Parents: Yes, we do. We've been to Zui Bai Pool in Song Jiang, and Pu Tuo Mountain. Last year we went to Feng Hua, ${ }^{14}$ the hometown of Chiang Kai Shek.

C's father: Last year when we were at Pu Tuo Mountain, she said that she didn't enjoy the place enough, and that she wants to go back again this year.

C's mother: She will have her annual leave for this year now. July is far too hot, so she can take a good rest and we will take her out in October, while both of us are still mobile. She's very happy if we take her traveling. Last year when we just returned from our trip, she already asked, "Mom, where are we going next year?" I said, "Let's decide then." And now it's the time, so she asked me, "Where are we going?" "For sure we will go somewhere," I said.

\section{Deep Love and Worries over the Future}

C's father: All the parents of the kids at special school share one common worry: One day we will be old, so what will happen to our kids when we pass away? We used to discuss this when we went to pick up our kids after school.

C's mother: What will happen to our child? This has always been our concern. I have been thinking about one possibility, to take her with us when we are dying. No other solutions.

C's father: Many parents have the same thought.

C's mother: Who can take care of her if she's left alone in this world? Nowadays people are not like previously... There are still people with loving hearts, but much less than before. And we don't necessarily have the luck to meet someone with loving hearts, do we? Therefore, I got this idea. Now that we are still around, we just take her out traveling, let her see more of the world and be happy. When our time comes, I would like to take her with us. Then I can rest in peace. That's my idea, and it's shared by lots of parents in the same situation. This is really an issue.

Q: Have you thought about letting her have her own family?

C's mother: No, we haven't. Honestly speaking, with our daughter's condition, it's still possible to find her a spouse, but we have concerns. If she gets married, she might be taken advantage of. Besides it takes quite some money. Even normal people have a high divorce rate. I'm afraid that it wouldn't work out for her. So, I've never taken this as an option. We two just hope that our health allows us to live longer, so that we can be with her happily, and take her out to see the world.

C's father: To show her the beauty of the world.

C's mother: China is beautiful, with magnificent scenery.

Q: Do you now still have that idea of taking her with you when you pass away? Parents: Yes, we do.

\footnotetext{
${ }^{14}$ Feng Hua: Scenic areas in suburban Shanghai, the neighboring Zhejiang and Jiangsu Provinces.
} 
Q: What if she gets settled well?

C's father: In the current society, even normal people can hardly settle well.

C's mother: Exactly. The younger generation cannot be compared with our generation. If we let her get married, we would spend a sum of money. We'd rather save that money for her to enjoy and to travel.

C's father: I just learned from the news that there were more than 3.8 million couples divorced last year in China. If she could meet a kind person who would take care of her, that would be the best. But people nowadays are very realistic. For example, if she gets married with someone with the help of a matchmaker, what might be his purpose? Would he just be kind to her or does he have a hidden agenda? Some people from provincial cities want to settle in Shanghai, and therefore they are willing to sacrifice and marry somebody inferior. We are just ordinary people, but if we were rich, people might marry her for the money, right? Many people have evil intentions. Nowadays good people are rare in society.

Besides we also have other concerns. This Papa John's restaurant has "loving" branches, where they accept this special group of kids. Before the Cultural Revolution, there were also many Welfare Factories under the National Civil Affairs Bureau. ${ }^{15}$ But these factories were all closed or unattended after the Reform and Opening Up. For example, at our work unit, there used to be factories under the same bureau where deaf people, dumb people, or people with hunchback and so on were accepted. They could accomplish some tasks requiring relatively simple techniques. But the state-owned enterprises won't recruit special groups of people like this anymore after the Reform and Opening Up.

C's mother: Yes. This is also our worry. Currently our child is doing well in Papa John's. But if this restaurant doesn't exist in the future, she will be jobless. After all, a family with a kid like this will always have worries. We as parents will always consider all different aspects. We are so worried. If society gets more prosperous, and people with disabilities can enjoy more welfare, like in foreign countries, that would be fine. I learned that in many foreign countries, people with disabilities are treated very well. If our economy could grow further, we wouldn't be so worried, right?

C's father: We have also seen reports about the living status and treatment of people with disabilities in foreign countries, as well as their policies for the treatment of people with disabilities. After reading these materials and comparing them with the situation in China, we still see a big gap.

Q: Where do you see the gap?

C's mother: To me, firstly, some people will look at these kids in an unfriendly light. Our daughter's problem is not so easy to be judged from her appearance. But for some kids, the look from others makes you very uncomfortable. It is mentioned in foreign newspapers that everyone is equal and nobody is weird. In this respect, it seems that people in China are less friendly. This might also be related to what quality of person they are.

\footnotetext{
${ }^{15}$ Welfare Factories: Government-run factories where people with physical or mental disabilities worked.
} 
Q: And what are the differences in terms of policies?

C's father: The treatment in foreign countries would be better. Possibly it is due to the huge population in China. It's difficult to take care of so many people.

Q: Have you checked in detail what the policies are like in each country?

C's father: No, we haven't. The information mainly comes from the chatting of the parents when we were waiting outside the school to pick up the kids.

C's mother: We do hope that China can be stronger and better, and then social welfare will be improved and these kids can live more happily. Right?

$\mathrm{Q}$ : Have you ever received help from the community?

C's mother: Yes, we have. Honestly speaking, I'm very grateful to the country and the Party. As ordinary citizens and a special family, we are treated well. The Shanghai Municipal Government implemented a policy in 2008, to provide subsidies to onechild families who lost their only child or families like us, where the kid is disabled but the parents don't have a second child.

C's father: Yes. Because we only have one child and $C$ has the Disability Certificate. So we are entitled to get the subsidy.

C's mother: C's salary is rather low. She just gets the minimum wage. But with the subsidy, it's much better.

Q: What was your consideration not to have a second child? In some families, they think that the second child might be able to take care of the first one.

C's mother: We just have never had this idea. Never.

C's father: Among the parents we know, some have considered having a second child. And some of them did have the second one, while the others didn't do it after consideration. Some think that in the future the younger child could help the elder one, while the others think that the elder one might become a burden for the younger one. It would be hard if the younger child gets married and still has to take care of the elder one. So they dropped the idea of having a second one. And for us, we just don't think about all these things. We just want to focus on this child and raise her up carefully.

C's mother: Imagine, no matter how your financial situation is, there are always some properties in a family. If two kids need to share, it would be hard to keep it fair. But if there's only one child, then it's all his or hers. That's how we look at it. So we've never thought about having a second one.

Q: Our interview is coming to an end. Parents, do you still have anything to add?

C's mother: We just hope that China can get stronger and more prosperous and that social security and other aspects could all be further improved. Then we don't have to worry and can feel a bit relieved. And we do hope that our daughter's job could be a long-term and stable one.

\section{Interview with C's Co-Worker (I)}

Interviewee: Restaurant Manager

Interviewers and writers: Zhuojun Zhang and Xiangmeng Huang 
Interview date: August 13, 2016

Interview place: Restaurant where $\mathrm{C}$ works

Q: When did C start working here?

Manager: Ever since this branch opened. Previously she worked at the Tian Lin Branch. The exact starting year I would have to look up. She was under my supervision at that time as well. Later Tian Lin Branch was closed. Actually, C lives closer to another branch, but because I've always been her supervisor before, her parents hoped that she could still follow me. Then she came with me to this branch. This restaurant opened in December 2014.

Q: How long has she been working with you?

Manager: It should be more than 3 years.

Q: Do you still remember the situation of her first working day at the Tian Lin Branch?

Manager: That I really can't recall, because when they just joined, I was not their trainer. We have a dedicated trainer in the kitchen who's responsible for the orientation of the employees. It normally takes 2-3 days. There was a colleague guiding her at that time, who is no longer working here.

Q: Just now I noticed that they need to do various things which are quite complicated. Did they all learn these things by themselves?

Manager: Yes, they did. They began with simple tasks. For example, grilling chicken wings is relatively easy. You only need to put them on the grill for a while. Other tasks might be more complicated, like preparing pasta, you need to know what should be added to the chicken pasta. She would take the written materials home and memorize the procedures. She takes it very seriously. She might do it a bit slowly, but she basically won't make any mistakes.

$\mathrm{Q}$ : She has been working for quite some time. You were her supervisor from the beginning. How does she perform now compared to when she just started? Are there any changes or progress? Or is everything the same?

Manager: I must say that there are improvements. Now no matter how complicated the tasks are, or how many more tasks she gets, she will be able to deal with them. She will spend time to memorize and to master the skill. For sure she has been making progress. Also, she used to be reluctant to talk, and was rather introverted. But now she will take the initiative to greet people, and she will voluntarily start a chat by saying, "Is my dress pretty? My mom bought it for me."

Q: How many employees being cared for like her are there in this restaurant?

Manager: There are five.

Q: So many! How many are here today?

Manager: Today there are three. All staff you see now in the kitchen are employees being cared for. Their situations are like this: we have $\mathrm{J}$, she has been working for a very long time and has been in my team since 2009. She is the trainer in the internal site. She is different from the rest of them. She is an employee being cared for because she got injured during her work previously. One of them you won't see today. She has problems with her hearing, but she is pregnant and is now on leave. The one you saw wearing a jade pendant is also intellectually disabled. She behaves like a 
child. She will keep on talking to you and can be rather chatty. Sometimes, she lacks self-control.

Q: Is she the one who just came over to chat with us?

Manager: That must be her. She is just like a kid who talks a lot. She likes talking to everyone. She has also been to some restaurants nearby in the neighborhood and talked there as well. That's because she can hardly tell what is appropriate. Sometimes the staff from other restaurants would tell me, "The girl from your restaurant is bothering us again" (smiling). She is that type of girl. And there's one more you won't see. She is now on her annual leave. Normally she teams up with $\mathrm{C}$ to prepare snacks together. So that's them, five in total.

Q: I have been observing when they were working. They are relatively slow.

Manager: Comparatively speaking, $\mathrm{C}$ is rather slow. The rest of them are fine.

Q: Would the customers ask them to hurry up? Would you also urge them accordingly?

Manager: If customers place a big order with many items, our duty manager would coordinate and help, to make sure that all items will be served to the customers on time. Sometimes if an item is missed, we would explain to the customer that we are a caring restaurant and that our situation is like that, and that we didn't monitor it well enough. Most customers would understand once we explain to them. Normally there won't be any big issue.

Q: Do you impose the same requirements on the employees being cared for as you do on the normal ones?

Manager: The requirements for the employees being cared for would be relatively low. For example, if normal employees can prepare a portion of pasta in $1 \mathrm{~min}$, they probably need 2 or $3 \mathrm{~min}$. For sure there will be deficiency. To be exactly the same is not possible.

Q: In what situation would you criticize them?

Manager: Ah, for example for repetitive mistakes. If they keep on making the same mistakes, our Front Desk Manager will criticize them. And that would be quite serious criticism. We've also communicated with the parents about that. The other thing we might criticize would be a lack of punctuality when it comes to work time. But normally we hardly criticize them. After all this is a special store and we have quite a lot of employees being cared for. So the level of strictness can be moderated.

$\mathrm{Q}$ : And in what situation would you praise them?

Manager: Ah, praising would be much easier than criticizing. For example, sometimes after preparing a portion of spaghetti, $\mathrm{C}$ would tell me, "I'm finished preparing, and I've wiped the table." Then I would say, "Well done, you've been working hard!" In such a situation, we will give verbal praise. Just a sentence like this and a smile, and they will be really happy.

Q: Has C ever been unpunctual?

Manager: No, she hasn't. C's parents will bring her to the bus station and then she will take the bus on her own to the restaurant. Her parents will wait for her at the bus station there again after her work. On windy and rainy days, her father will come to the restaurant to get her home. $\mathrm{C}$ has probably never been late for work due 
to a personal reason, in my impression not even once. She also seldom asks for sick leave.

Q: What are their working hours? From 11a.m. until when in the evening?

Manager: The working hours are from 10 a.m. to 7 p.m., with a 1-hour break in-between. Eight hours every day. This morning we had some activities here, so we've asked you to come a bit later. Actually, we started from 10 a.m.

Q: Did you have the same working hours in the previous branch?

Manager: Yes, we did. Oh no, in that branch we worked from 11 a.m. to 8 p.m. But it was still $8 \mathrm{~h}$ a day. That's the same. It is busier in the morning at this branch, therefore we start earlier.

Q: Does $\mathrm{C}$ have more interaction with employees being cared for like herself, or with normal ones?

Manager: $\mathrm{C}$ works in the internal site, where there are more staff of her type. For example, you've seen $\mathrm{W}$, who likes talking. C has more contact with her. Normally she will also talk quite a lot to me. She will come over and tell me that her mom has bought her a pair of new shoes, or a new bowtie. She probably won't take the initiative to talk to the other supervisors. After all, she has known me for a long time. As for the other colleagues, she has more communication with the staff in the internal site. That's not so much because they are of the same type, but more because they work in the same space. That might be the reason.

Q: Are you and C contacts on WeChat?

Manager: Yes, we are.

Q: Do you usually have interactions on WeChat Moments?

Manager: C seldom posts on Moments. Occasionally she will post several photos when she travels. During New Year or other festivals, when we all receive some messages with wishes, we might forward them to each other. Nothing more than that. Besides, we have a working team group on WeChat, where we would post notices to everyone. $\mathrm{C}$ will respond to that. Sometimes we perform well and the branch gets a reward, we will hand out Red Packets in the group chat, and will ask her to retrieve them. ${ }^{16}$

Q: What would be your overall comment on $\mathrm{C}$ as an employee here?

Manager: To me, she is a rather introverted employee. But that's not a problem for her work. Her performance in her work is very satisfactory.

\section{Interview with C's Co-Worker (II)}

Interviewee: J (co-worker from the kitchen)

Interviewers and Writers: Xiangmeng Hua and Zhuojun Zhang

Interview date: August 13, 2016

Interview place: Restaurant where $\mathrm{C}$ works

${ }^{16}$ Red Packets: Bonuses wrapped in red envelopes. For WeChat, it refers to bonuses in digital form. 
Q: How long have you been working together with C?

J: Should be 1 or 2 years. We were colleagues before the opening of this branch, when Tian Lin Branch was still open.

Q: Who started working there earlier, you or C?

J: I started earlier.

Q: Did you train her?

J: Yes, I did. But actually, she first started at Nan Zhan Branch, before she went to Tian Lin Branch. When she worked at Nan Zhan Branch, she had already been trained, and had learned some basic tasks. Whenever new items are launched, I will teach her and demonstrate it to her.

Q: In daily work, does she arrange the procedures by herself, or do you tell her about what to do first and what to do next, and then she follows your instruction?

J: Every time we will make the arrangement and then tell her. Normally she won't ask by herself. We will have to instruct her and then she will do it. For example, when we finish the tasks for one order, we should clean up the table. We normally need to ask her to do it, otherwise she won't do it.

Q: Do you usually have much contact with her in your private time?

$\mathrm{J}$ : Not much. C doesn't like talking and is timid and quiet. During meals we will just eat on our own. During working hours, we will talk about work-related issues. But in general we don't talk much. If you talk to her, she will respond. But she won't voluntarily start a conversation.

Q: If not for the work, what would you chat about?

J: We hardly chat. Another colleague talks more with her.

\section{Interview with C's Co-Worker (III)}

Interviewee: A co-worker from the dining area

Interviewers and writers: Xiangmeng Huang and Zhuojun Zhang

Interview date: August 13, 2016

Interview place: Restaurant where $\mathrm{C}$ works

Q: We mainly would like to get a rough idea about your interaction with $\mathrm{C}$.

Co-worker: Interaction with her in particular?

Q: Or you can talk about your interaction with the group of employees being cared for.

Co-worker: They are all quite similar. They work, eat, and rest according to the schedule. After eating, they will play with their mobiles. When rest time is up, they will go back to their respective posts.

Q: Does C normally communicate with you?

Co-worker: $\mathrm{C}$ is a timid kid who hardly talks.

Q: She is rather introverted and doesn't talk much?

Co-worker: Right, she doesn't talk much. How many employees being cared for are there at our branch? About four or five. Another one is rather strange. She talks 
to people everywhere. And we have J. I'm not sure what her problem is. To me, J is the same as normal people. It is said that $\mathrm{J}$ is in a similar situation to $\mathrm{C}$ and others. But I can't tell. I feel like J is normal. Another one has poor hearing. She's pregnant and is now on leave. Apart from her hearing I think she must be pretty normal.

Q: Do you usually have much communication with staff from the internal site?

Co-worker: Do you mean with the employees being cared for?

Q: Yes.

Co-worker: Ah, these ones, we hardly talk to them if there's nothing in particular.

Q: Hardly any contact, right?

Co-worker: Right. And probably I have the least contact with C. We regard J as a normal person. And the other one with hearing problems, she can figure out what we say by reading our lips, though she couldn't hear clearly. $\mathrm{C}$ is normally timid but smiles a lot.

Q: So you don't have much contact with them in your private time, do you?

Co-worker: No, I don't. We all know about their situations and don't have much communication with them. But we won't look down on them. That won't happen in our branch. Discrimination doesn't exist here. Our branch is like that. We all respect each other.

Q: Did you know that there are employees being cared for here before you came to work at this branch?

Co-worker: No, I didn't. I only learned about it after I came here. Then I felt that it's actually quite nice here in Shanghai. If they were in my hometown, they might not be able to find a job. My hometown is in a rural area. They could probably only stay at home. And now they can work here. At least they can contribute to the pension fund, so they can have a secure life when they get old. This job is not super tiring. Sometimes we might also have some idle time.

\section{Interview with Ms. C}

Interviewee: Ms. C (accompanied by the Restaurant Manager)

Interviewers and writers: Xiangmeng Huang and Zhuojun Zhang

Interview date: August 13, 2016

Interview place: Restaurant where $\mathrm{C}$ works

Q: Tell us how you spend your day every day. Approximately when do you normally get up every morning?

C: Around 6 o'clock. And then get breakfast ready.

Q: Do you mean prepare breakfast or eat breakfast?

C: Eat breakfast.

Q: Do you prepare breakfast for your parents when you are home?

C: No, I don't.

Q: What time do you usually leave home? When do you set off to catch the bus?

C: Around 8 o'clock. 
Q: And about what time do you get to the restaurant?

C: Nine o'clock.

Q: You already arrive by 9 a.m.?

Manager: Normally she does arrive immediately after 9 a.m.

Q: We've heard from your parents that the bus sometimes might change the route and wouldn't bring you to the restaurant. Were you scared or nervous when that happened?

C: I was.

Q: Do you still remember how you coped with that situation?

C: I would then come by taxi.

Q: You have your breakfast so early, and will only have lunch during the break around 2 or 3 p.m. Will you feel very hungry when you are preparing snacks?

C: No, I won't.

Q: Okay. When is normally your busiest moment? Is it when you just start your day? Or do you get busier after a while?

(C didn't answer.)

Manager: Normally lunch time is our peak hour every day. They start working at 10 a.m. by doing some preparation jobs. $\mathrm{C}$ will cut some vegetables and wrap some bacon rolls or things like that. Between approximately 11:30 and 12:30, there will be an hour of really busy time. Around 1 p.m. onwards it will be a bit easier for her.

Q: Until when does she have free time?

Manager: The easy time after 1 p.m. doesn't mean that she has nothing to do. She will wipe the tables and wash the bowls and dishes on her post. By then it would be almost 2 p.m., time for them to eat. After eating she will get back to her post to do cleaning. We do cleaning every day. For example, today she will soon go to wash the cart. We take turns to wash the cart, once a week for everyone. The build-up of corn flour should all be washed away.

Q: Do you have your dinner in the restaurant or at home?

C: I always go home for dinner.

Q: When do you normally arrive home?

C: Usually at 7 o'clock.

Q: And when do you go to bed at night?

C: I go to bed after taking a shower.

Q: So around 10 or 11 o'clock?

(C didn't answer)

Manager: I guess it would be around 9 or 10 o'clock. She might not be so precise about time. I guess that she would be home at around eight, because she finishes her work at seven. Then she would eat and take a shower. She might watch some TV after dinner and then go to bed. So it should probably be around 9 or 10 o'clock, I think. You might get a precise answer if you ask her parents about this.

Q: On the first day of your work, did your parents accompany you here, or did you come here by yourself?

C: My parents brought me here.

Q: Okay, so your parents brought you here. How long have they been doing this?

C: That I don't remember. 
Q: Were you nervous on your first working day?

C: No, I wasn't.

Q: Wow, you weren't nervous! Do you still remember which tasks you did that day? Did somebody teach you something? Or did they just ask you to prepare food right away for the customers out there?

C: They did teach me how to do things.

Q: I saw that today you have made many different types of snacks. Which one do you like to make?

C: I like Tasty Combo. (The word "tasty" was pronounced a bit unclearly.)

Q: So, you like preparing combo dishes. What kind of combo dish is that?

Manager: Tasty Combo is composed of chicken wings, potato wedges, and potato stars. It's also our best-selling combo dish.

Q: Why do you like preparing this one?

C: It's simple.

Q: Okay, and which one do you dislike to prepare most?

C: I don't dislike any of them.

Q: Haha!

Manager: There's something I'd like to add. C makes the best-looking pasta and rice dishes in our restaurant. It's true. They are the prettiest. Because she's very careful, so the ones she prepares look especially nice.

$\mathrm{Q}$ : For the combo dish $\mathrm{C}$ prepared just now, does $\mathrm{C}$ only need to put everything onto the board?

Manager: Yes, that one is Tasty Combo, with potato stars, potato wedges, and chicken wings. That one is prepared by $\mathrm{C}$.

Q: Is she just responsible for the arrangement of ingredients on the board? Or is she also responsible for the frying?

Manager: We don't have deep-fried items. She just needs to put things onto the baking tray, and place the tray on the oven rack. For example, if an order for Tasty Combo comes, she only needs to put everything in according to the list.

$\mathrm{Q}$ : C, could you describe the detailed preparation procedure of a certain snack? For example, how to make chicken wraps?

Manager: Let's give it a try. C, could you tell them (pointed at the interviewers) how you make chicken wraps? So, you would first take two tortillas, and put what in them? And then what do you do? Lastly you put them into the oven. Let's try it. It doesn't matter. Come on, say it slowly. So first take two pieces of 6-inch tortilla, and then? You don't have to be nervous.

(C did not respond.)

Manager: Otherwise I could let her prepare one later, and then you could record down the procedures. Because if you ask her to say it, she probably gets very nervous.

Q: Oh no, it doesn't matter. We could record it down later when we observe her work. Don't make her specially prepare one for us. (Facing C) Sorry that we made you nervous. Please don't be nervous. It doesn't matter. We are just chatting.

(In order to let $\mathrm{C}$ relax, we changed the subject to traveling.)

Q: Have you had a trip recently?

C: Yes, I have. 
Q: Where did you go?

C: We went to see lotus flowers.

Q: Where did you see lotus flowers? Somewhere in Shanghai?

C: I have photos.

Manager: You have photos. Good, then can you show them to us? Find your photos and let everybody have a look.

( $\mathrm{C}$ took out her mobile and searched for the photos. Everyone looked together.)

Manager (to $\mathrm{C}$ ): Do you know where it is?

(C didn't answer.)

Q: Ah, where is this? Is it in Shanghai? Or in another city?

C: I don't know either.

Manager: Did you sit long in the car?

C: No, not so long.

Q: Did you go by train or by bus?

C: We went by bus.

Interviewers and Manager: Oh, by bus. Then it must be in Shanghai.

Manager: (Browsing the photos) These are all photos of her parents.

Q: Did you take all these photos?

C: My parents asked me to take all these photos.

(We finished browsing the photos, and $\mathrm{C}$ was about to put away her mobile.)

Q: How long was your trip? Was it within 1 day?

C: Yes, just 1 day.

Q: Okay, you went there and came back on the same day.

C: Yes, we did.

Q: Do you like traveling?

C: Yes, I do.

Q: Which do you prefer, staying at home or going out traveling?

C: Traveling.

Q: And do you like your work?

C: Yes, I do.

Q: Do you prefer staying at home or going to work?

C: I prefer going to work.

Q: So, you prefer going to work (laughing). Why do you like to work? Is it because at work you could make the things you want to make? Or is it because you would be happier with your colleagues?

C: Because I like making things.

Q: Do you think it's difficult to prepare dishes and snacks?

C: No, not difficult.

Q: Have you ever made a mess or made a mistake? Do you remember that? For example, when you just started with your job and you weren't yet familiar with it.

C: I don't remember.

Q: Have you ever been scolded by the Restaurant Manager?

C (answered briskly): No. 
Q: Which snack do you think is the most complicated one to prepare? So complicated that every time you need to think over how you should make it. Which is the most difficult one?

Manager: Which item is the most difficult one for you to prepare? Which one takes the most time?

C: Brilliant Combo. (The word "brilliant" was pronounced a bit unclearly.)

Manager: Oh, our new product, called "Brilliant Combo." And the other one "Luxury Combo" is even more complex, but doesn't have many ingredients. "Brilliant Combo" includes many ingredients and is therefore rather complicated to put together.

Q: What is Brilliant Combo composed of?

Manager: Chicken pieces, uh, I don't remember (laughed). Let me get the menu. (Manager came back with the menu.)

Manager: This is quite complex, especially this Phuket Tower.

Q: It includes a lot of items-one, two, three, and four.

Manager: These items are not difficult for her. But the new Phuket Tower is troublesome to make, the rest is easy for her. It took her a lot of effort to memorize all that.

Q: When you learn a new dish, how do you usually learn it? What are the procedures?

Manager: Like the new products we have this time, how did J train you? Explain to them (pointing at the interviewers).

(C didn't answer.)

Manager: That day J made it one time to demonstrate, didn't she? Did she let you make it once by yourself afterwards?

C: No.

Manager: And the next day she gave you the training again. She taught you one more time, right? Did she let you do it by yourself then?

C: No.

Manager: Also not. So, she demonstrated to you twice. The first day, did she give you materials for you to take home and to memorize? Did she do that?

(C didn't answer.)

Manage: Normally a dedicated person would demonstrate to her. We first train J. She is the trainer. And then J can train them. One new product is taught each day. Then they would get a sheet with training material. They can take it home to memorize. $\mathrm{C}$ will always carry that sheet with her.

Q: With which colleagues do you have closer contact?

C: With $\mathrm{W}$ and $\mathrm{J}$.

Q: What are the things you chat about?

C: We chat all about the snacks.

Q: And anything besides the work?

(C didn't answer.)

Manager: What do you normally talk about with $\mathrm{W}$ and J besides work?

C: Normally W would tell me things about her family. 
Manager: Then these topics we shouldn't share with them (pointing at the interviewers). We shouldn't tell them W's family affairs.

Q: Do you normally take initiative to chat with your colleagues?

C: No, I don't.

Q: Just now the Restaurant Manager told us that you would voluntarily tell her that today you are wearing a pretty dress. Things like that, would you also voluntarily tell other people?

C: No, I wouldn't.

Q: So you are more familiar with the Restaurant Manager, right?

C: Yes, more familiar.

Q: Let's then talk about things at your school. Do you still remember a lot from your school time? For example, there were many activities organized by JiXun School. Do you still remember?

C: Yes, I do.

Q: What are the activities that you still remember? Could you share some with us? Activities that you liked to participate in.

C: I liked the Haibao Exercise. ${ }^{17}$

Q: Was it during Expo?

C: Yes, it was.

Q: Was this Haibao Exercise a group exercise you practiced then?

C: Yes, it was.

Q: Then you performed in front of the audience? Or was it just for yourselves?

C: We performed it.

Q: Where have you performed?

C: At school.

Q: Did you go to other schools? Or was it at your school?

C: At our school.

Q: Okay, so you performed the Haibao Exercise at your school. Why did you like it?

C: The colors are pretty.

Q: Pretty colors. Did you all wear different colors of clothes?

C: We all wore blue clothes.

Q: Were there any other activities at school that you liked or you had an impression of? For example, did the school organize trips to suburban areas, or to the cinema and so on?

C: No.

Manager: She probably doesn't remember anymore.

Q: Do you remember the subjects you had at school? Which were your favorites?

C: Physical Education.

Q: So Physical Education was your favorite. Which sport were you good at?

C: Bouncing the ball.

Q: Is there any sport that you were not so good at? For example, you like all others, but this particular one is a bit difficult?

\footnotetext{
${ }^{17}$ Haibao: Meaning "jewel of the sea," was the mascot of Expo 2010, held in Shanghai, China.
} 

C: No.
Q: No? So did you like going to school?
C: Yes, I did.
Q: Going to school and going to work, which one is more fun? Or both are almost equally fun?
C: Equally fun.
Q: Why did you like going to school? Was it because there were a lot of classmates?

Or was it because there were subjects that you liked?

(C didn't answer.)

Manager: Don't know the reason, but liked it anyway. $\mathrm{C}$ is a rather simple kid.

Q: Were there teachers that you liked at school?

C: My Chinese teacher.

Q: Was that a male or a female teacher?

C: A female teacher.

Q: What were the things that you liked about her? Did you feel that her lessons were good, or did she take good care of you?

C: Her lessons were good.

Q: What was the content of her lessons? Did she tell interesting stories? Or did she teach you how to write?

C: She taught us how to write.

Q: Did you make some good friends at school?

C: Yes, I did.

Q: Do you now still keep contact with them?

C: Yes, I do.

Q: How do you get along with them? Do you take the initiative to chat with them? Or, do they come to you to chat?

C: Normally they come to me to chat.

Q: Have you invited classmates to your home to play?

C: Yes, I have.

Q: Apart from family members, colleagues and friends from before, do you have contact with other people? Do you play with others?

C: No, no other people.

Q: Is it because your mom has instructed you not to talk to strangers?

C: Yeah, she did tell me that.

Q: And do you want to have contact with people from the outside world?

C: I won't have contact with them.

Q: When you are at home, would you occasionally make some snacks you learned in the restaurant for your parents?

C: We don't have an oven at home.

Interviewers and Manager: Ah, no oven.

Manager: Normally we would hold a "Family Night" when a new branch opens. Then we would invite the staff and their parents to eat in our restaurant. The parents could have a look at the environment, and meet the supervisors. Then they would be more rest-assured when their kids start working here. So, the snacks couldn't be made at home. 
Q: We have learned from your parents that at school, you were also taught how to make dishes, like fried eggs with tomatoes. Would you make them for your parents?

C: Yes, I would.

Q: Have you cooked for them recently?

C (Answered with absolute certainty): No.

Q: (Everyone laughing) So what would you usually do at home when you are free?

C: Play on the computer and watch TV.

Q: What do you do on the computer? Surf or playing games?

C: I usually watch TV series.

Q: So you watch TV series on the Internet. Which one are you watching lately?

C: The Journey of Flower. ${ }^{18}$

Q: Do you have any favorite actors or actresses?

C: I like Liying Zhao. ${ }^{19}$

Q: Ah, Liying Zhao. Do you think that she is very pretty?

C: Yes.

Q: Have you watched any Olympic events lately?

C: No, I haven't.

Q: Normally do you find the work here tiring?

C: No, I don't.

Q: Are you happy every day?

C: Yes, very happy.

Q: Let's make an assumption, just an assumption. The branch where you worked previously was closed, right? In case this branch would also be closed, what kind of other jobs do you want to do?

C: I've never thought about it.

Q: Do you want to keep on making snacks in this restaurant all the time?

C: Yes, I do.

\section{Observation of C at Work}

Observation date: 11:00-19:00, August 13, 2016

Observation place: Restaurant where $\mathrm{C}$ works

Observers and writers: Zhuojun Zhang and Xiangmeng Huang

\footnotetext{
${ }^{18}$ A popular love story between a master and his disciple, released in 2015.

${ }^{19}$ Liying Zhao: The lead actress in the TV series The Journey of Flower.
} 


\begin{tabular}{|c|c|c|}
\hline Time & What $\mathrm{C}$ did & Remarks \\
\hline 11:00 & Observers enter the restaurant & $\begin{array}{l}\text { The "Pizza Parenting Class" Event is held } \\
\text { in the restaurant. Many families with kids } \\
\text { are eating here }\end{array}$ \\
\hline $11: 26$ & $\begin{array}{l}\mathrm{C} \text { peels off the foil around a surimi stick, } \\
\text { cuts the sticks into small pieces, and } \\
\text { places them into the designated container }\end{array}$ & $\begin{array}{l}\text { This is a daily routine task of cutting and } \\
\text { preparation }\end{array}$ \\
\hline $11: 32$ & $\begin{array}{l}\text { C puts the ingredient container with } \\
\text { surimi sticks back in its designated } \\
\text { position on the ingredient table, returns to } \\
\text { the preparation table, sorts out and } \\
\text { disposes the plastic foil from the surimi } \\
\text { sticks }\end{array}$ & $\mathrm{C}$ is very careful, but acts relatively slow \\
\hline $11: 38$ & $\mathrm{C}$ enters the freezer to get things & $\begin{array}{l}\text { C greets the observers on her way back to } \\
\text { her preparation table }\end{array}$ \\
\hline $11: 42$ & $\begin{array}{l}\mathrm{C} \text { arranges semi-finished chicken wings } \\
\text { on the baking tray and places the tray into } \\
\text { the oven }\end{array}$ & \\
\hline $11: 43$ & $\begin{array}{l}\mathrm{C} \text { takes out a bag of semi-finished } \\
\text { chicken wings and refills the chicken } \\
\text { wing container }\end{array}$ & \\
\hline $11: 49$ & $\begin{array}{l}\text { Duty Manager tells } C \text { to prepare three } \\
\text { dishes on the order: lemon spaghetti, } \\
\text { spaghetti bolognese and seafood baked } \\
\text { rice }\end{array}$ & $\begin{array}{l}\text { It seems that } \mathrm{C} \text { doesn't hear. She keeps on } \\
\text { cleaning up the countertop of the } \\
\text { preparation table }\end{array}$ \\
\hline $11: 53$ & $\begin{array}{l}\text { A colleague tells } \mathrm{C} \text { that she is now } \\
\text { expected to make lemon spaghetti. } \mathrm{C} \\
\text { collects ingredients needed at the } \\
\text { ingredient table and goes into the freezer } \\
\text { for a pack of sauce }\end{array}$ & $\begin{array}{l}\text { Whenever the Manager or the colleagues } \\
\text { expect C to prepare a certain dish, they } \\
\text { will say, "C, please make this." }\end{array}$ \\
\hline 12:07 & $\begin{array}{l}\text { When } C \text { was in the freezer, a colleague } \\
\text { finished her half-done lemon spaghetti. } \\
\text { So the colleague asks } C \text { to continue with } \\
\text { spaghetti bolognese }\end{array}$ & \\
\hline $12: 15$ & $\begin{array}{l}\text { C receives another order request for three } \\
\text { products: rice, noodles and two chicken } \\
\text { wraps. C goes to the ingredient table, } \\
\text { collects the ingredients and places } \\
\text { chicken wraps into the oven }\end{array}$ & $\begin{array}{l}\text { A colleague prepares the rice and noodles } \\
\text { at the same time }\end{array}$ \\
\hline $12: 25$ & $\begin{array}{l}\mathrm{C} \text { receives a new order request, prepares a } \\
\text { portion of spaghetti and packs it into a } \\
\text { takeaway box }\end{array}$ & \\
\hline $12: 27$ & $\begin{array}{l}\mathrm{C} \text { collects ingredients at the ingredient } \\
\text { table, and comes in and out of the freezer } \\
\text { to collect more ingredients }\end{array}$ & $\begin{array}{l}\text { It is a weekend, so there are just a few } \\
\text { dine-in guests. Most orders are for } \\
\text { takeaway. After 12:30, orders get less. C's } \\
\text { workload is less }\end{array}$ \\
\hline
\end{tabular}


(continued)

\begin{tabular}{|c|c|c|}
\hline Time & What $\mathrm{C}$ did & Remarks \\
\hline $12: 29$ & $\begin{array}{l}\text { C sorts out and cleans her preparation } \\
\text { table, washes and brushes the used tools, } \\
\text { pans and bowls }\end{array}$ & $\begin{array}{l}\mathrm{C} \text { completes the task together with } \\
\text { colleagues }\end{array}$ \\
\hline $12: 40$ & $\begin{array}{l}\mathrm{C} \text { looks at the order request, and prepares } \\
\text { a portion of potato stars }\end{array}$ & \\
\hline 12:42 & C continues with cleaning of the tools & \\
\hline $12: 45$ & $\begin{array}{l}\mathrm{C} \text { is instructed to prepare a portion of } \\
\text { potato wedges. } \mathrm{C} \text { bakes them }\end{array}$ & \\
\hline $12: 47$ & $\begin{array}{l}\text { C continues with cleaning of the tools. } \\
\text { After washing hands, } \mathrm{C} \text { notices that there } \\
\text { is not enough paper towel. C enters the } \\
\text { warehouse, gets some paper towels out } \\
\text { and refills the box }\end{array}$ & \\
\hline $12: 50$ & $\begin{array}{l}\mathrm{C} \text { finishes the task and returns to her post } \\
\text { waiting }\end{array}$ & \\
\hline $12: 57$ & $\begin{array}{l}\mathrm{C} \text { bakes potato stars, and pours some } \\
\text { semi-finished potato stars into the } \\
\text { container }\end{array}$ & \\
\hline 13:00 & $\mathrm{C}$ is waiting at her post & \\
\hline $13: 15$ & $\begin{array}{l}\mathrm{C} \text { begins washing lids of various } \\
\text { ingredient containers at her post, and } \\
\text { closes the lids again after washing }\end{array}$ & $\begin{array}{l}\text { Up to now the morning tasks are almost } \\
\text { finished. Afterwards } C \text { still has to make } \\
\text { several snacks, and then has the cleaning } \\
\text { task to do }\end{array}$ \\
\hline 14:00 & $\begin{array}{l}\text { One-hour lunch break begins. C eats } \\
\text { lunch and fruit, takes a rest and checks } \\
\text { her mobile }\end{array}$ & $\begin{array}{l}\mathrm{C} \text { is rather introverted, and hardly talks to } \\
\text { colleagues }\end{array}$ \\
\hline 15:00 & Lunch break ends. $\mathrm{C}$ is interviewed by us & \\
\hline 16:00 & $\begin{array}{l}\mathrm{C} \text { starts the weekly cleaning task to clean } \\
\text { the dough cart }\end{array}$ & $\begin{array}{l}\text { Weekly cleaning is scheduled for big } \\
\text { devices. The cleaning tasks of each day } \\
\text { are different, e.g., cleaning the fridge, or } \\
\text { wiping stainless steel surfaces, etc. A shift } \\
\text { schedule for the weekly cleaning hangs in } \\
\text { the restaurant, with everyone's duty listed }\end{array}$ \\
\hline $17: 30$ & $\begin{array}{l}\mathrm{C} \text { receives an order request. } \mathrm{C} \text { makes } \\
\text { potato stars, potato wedges, and chicken } \\
\text { wings }\end{array}$ & \\
\hline $17: 38$ & $\mathrm{C}$ cleans and wipes hands & \\
\hline $17: 43$ & $\mathrm{C}$ is waiting & \\
\hline $17: 52$ & $\begin{array}{l}\text { C sorts out baking trays, refills } \\
\text { ingredients, and bakes a portion of } \\
\text { chicken wings }\end{array}$ & \\
\hline
\end{tabular}


(continued)

\begin{tabular}{l|l|l}
\hline Time & What C did & Remarks \\
\hline $18: 03$ & $\begin{array}{l}\text { C makes grandma's pudding bread. C gets } \\
\text { milk and bread cubes, stirs the sauce, } \\
\text { arranges yellow potato paste on board, } \\
\text { covers it with sauce, spreads dried raisins, } \\
\text { and places the board in the oven }\end{array}$ & $\begin{array}{l}\text { Duty Manager says that this is a rather } \\
\text { complex dessert }\end{array}$ \\
\hline $18: 13$ & $\begin{array}{l}\text { C adds rice into a takeaway box, stirs } \\
\text { sauce, pours it on the rice, spreads meat, } \\
\text { goes to another ingredient table to } \\
\text { sprinkle cheese, and places the dish in the } \\
\text { oven }\end{array}$ & $\begin{array}{l}\text { This one has a beautiful name: } \\
\text { Casablanca grilled chicken rice }\end{array}$ \\
\hline $18: 23$ & $\begin{array}{l}\text { C looks at the order request, makes rice, } \\
\text { and tears off the order request }\end{array}$ & \\
\hline $18: 25$ & $\begin{array}{l}\text { C makes chicken wraps and bakes } \\
\text { chicken legs }\end{array}$ & \\
\hline $18: 27$ & C washes tools & $\begin{array}{l}\text { C makes spaghetti and bakes potato } \\
\text { wedges }\end{array}$ \\
\hline $18: 32$ & $\begin{array}{l}\text { C washes tools, sorts out the preparation } \\
\text { table, and cleans the lids of each } \\
\text { ingredient container }\end{array}$ & \\
\hline $19: 00$ & C finishes work & \\
\hline 18
\end{tabular}

Translated by Ding Ying Edited by Andy Boreham and Zijian Chen

Open Access This chapter is licensed under the terms of the Creative Commons Attribution 4.0 International License (http://creativecommons.org/licenses/by/4.0/), which permits use, sharing, adaptation, distribution and reproduction in any medium or format, as long as you give appropriate credit to the original author(s) and the source, provide a link to the Creative Commons license and indicate if changes were made.

The images or other third party material in this chapter are included in the chapter's Creative Commons license, unless indicated otherwise in a credit line to the material. If material is not included in the chapter's Creative Commons license and your intended use is not permitted by statutory regulation or exceeds the permitted use, you will need to obtain permission directly from the copyright holder.

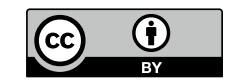

